\title{
Szakmaiság politikán innen és túl - aki az 50-es években is gojzer varrott cipőt hordott
}

\author{
2018. április 13-án a Budapesti Corvinus Egyetem Faculty Clubjában Sipos Júlia \\ beszélget Laki Árpáddal, aki vasokleveles egykori hallgató, később állandó oktató volt, \\ nemzedékek számviteli képzése füzödik nevéhez. ${ }^{1}$
}

\section{Csipkedd magad, gólya!}

Sipos Júlia: Azt tudom önröl, hogy 1950-ben végzett, és 1948-tól 1990-ig, az ebben az idöszakban többször is nevet váltó egyetem oktatója volt a Számvitel Tanszéken. Hogyan kezdödtek közgazdász tanulmányai? Laki Árpád: Röviden arról, hogyan jutottam Budapestre. Egy kis zalai faluban éltem, öttagú családban, három fiú és a szülök. Anyám fixa ideája volt, hogy a fiait olyan helyzetbe hozza, hogy nyugdíjas állásuk lehessen. A Horthy-korszakban alapjaiban csak állami intézményeknél és a nagy multi cégeknél volt nyugdíj, egyébként nem. A társadalom döntő részében nem volt. Anyagi hátterünk annyit megengedett, hogy a két bátyám a négy polgárit végezte, de nekem várnom kellett, hogy ők kifussanak, így hat elemit végeztem. A hat elemi után anyám szeretett volna gimnáziumba adni, de a felvétel idején elmúltam 12 éves és akkor már első gimnáziumba nem vettek fel. Így az őszi pótbeíratáskor a polgáriba iratkoztam be, és vonatos diákként jártam iskolába. Reggel fél hatkor indultam és délután 5-kor értem haza, se napközi, se menza, semmi. Természetes volt, ebben az időben ez így ment. Kitünően végeztem a polgárit, és ha gimnáziumba szerettem volna menni, akkor különbözetit kellett volna tenni, így kereskedelmibe mentem. Zalaegerszegen a kereskedelmiben megpályáztam a Kereskedelmi és Iparkamara ösztöndíját. Évi 200 pengős ösztöndíjat kaptam, amiből 80 pengőt az iskola kapott tandíjtérítés címen, 120-at a szülö. Ennek a 120-nak a fele a vonatbérletre volt jó. De mindenesetre nagy segítség volt. Apám halála és anyám betegsége után a második kereskedelmit úgy tudtam folytatni, hogy Nagykanizsára mentem az unokanővéremhez. Ök tartottak el és segítettek, így Kanizsán érettségiztem, jeles eredménnyel. Öszintén szólva kereskedelmi érettségivel nem is lehetett más egyetemre menni, mint közgazdaságira. Anyám azt mondta: Fiam, ne menj, mert éhen halsz, én nem tudok segíteni. Megpályáztam a kollégiumot, kaptam kollégiumi ellátást. Akkor a kollégium Budapesten a legnagyobb fiúkollégium volt. Eredetileg nem volt koedukált kollégium, ez csak 1945 után jött divatba. Az Üllői út és a Körút sarkán volt, mégpedig ott, ahol a főváros helyőrségi laktanyája: egy négy utca határolta épület, amelyiknek egy részét a kultuszkormányzat valamikor a 20-as évek közepén megkapta és itt hozott létre egy fiúkollégiumot. Itt átlagban 300-350-en voltunk. Színes volt a társaság, mindenféle szak képviseltette magát, színész, zenész, orvos, jogász, közgazdász. Ideális hely mind társadalmi összetételében, mind szakmai felkészültségében. Az ember sok olyan ismeretet fölszedett, amelyről nem is tudta, hogy létezik, de ha nincsen ott, akkor nem szedi fel.

\section{S. J.: Ön eredetileg a József Nádor Müszaki és Gazdaságtudományi Egyetemre iratkozott be.}

L. Á.: Olyan intézményt kerestem, ahol nem kellett tandíjat fizetni. A kollégium ebédet és vacsorát biztosított, a többit úgy oldottam meg, ahogy tudtam. Rögtön olyan közegbe kerültem be, ahol többen is

\footnotetext{
${ }^{1}$ A beszélgetés alapja a BCE Digitális Audiovizuális Történeti Archívuma számára készült videófelvétel, ami az Egyetemi Levéltárban kutatható. A közreadott szöveg ennek írásos, szerkesztett és stilizált változata.

DOI: 10.14267/RETP2021.02.18
} 
hasonló helyzetben voltunk, és a többiek már tudták, hogyan lehet zsebpénzhez jutni. Ilyen volt télen a hóhányás, 1945 őszén rögtön a pártplakátok ragasztása az első választás után. Az idősebb kollégistáknak már megvoltak a kapcsolatai. Előfordult, hogy két kollégista előttem ragasztotta a Nemzeti Parasztpárt plakátját. Adtak hozzá kulimászt, plakátot meg vödröt. Mi mentünk utánuk. Sima plakátra nagyon könnyü ragasztani, ráragasztottuk a kisgazda plakátot és megkaptuk ennek az ellenértékét. A harmadik évtől már nem volt gondom, mert harmadéves koromban kerültem be a Számvitel Tanszékre. Ide is úgy kerültem, hogy az egyik kollégiumi szobatársam már bent volt, mint gyakornok és azt mondta: "Csipkedd magad, gólya, számvitelből és akkor el tudom intézni, hogy gyakornoknak felvegyenek!" Így kerültem be harmadéves koromban a Számvitel Tanszékre, és a kapcsolatom az egyetemmel 70 éves koromig tartott.

\section{Rendszer- és egyetemváltozás}

\section{S. J.: Hogyan emlékszik, kik voltak az Ön számára emlékezetes előadók, később kollégák?}

L. Á.: Ha visszagondolok a régi egyetemre, ott olyan szellemet, olyan miliőt tapasztaltunk, mint bármelyik másik egyetemen. Heller Farkas mellett ott tanított Erődi-Harrach Béla - szintén neves közgazdász professzor -, és amikor félév elején fel kellett venni a tárgyakat, a kollégista társaktól kértem tanácsot, hogy melyik előadást vegyem fel. „Az attól függ, hogy vizsgázni akarsz, vagy elmélyülni a közgazdaságtanban.” Persze, hogy vizsgázni akartam. Ezért jelentkeztem Erődi-Harrach óráira, de ott nem volt tankönyv. Bejön Erődi-Harrach és azt kérdezi, hogy mivel nincs tankönyv, ki vállalja, hogy leírja az órán elmondottakat. Felállnak néhányan, kérdezgeti, hogy ki milyen szótagszámmal tud gyorsírni:

- Kisasszony, mennyivel ír?

$-50$.

$-240 \ldots$

- Jól látom, hallgató úr, ön is jelentkezik? Mennyivel ír?

- 620. - Felhördülnek.

- Mi az ön foglalkozása?

- Parlamenti gyorsíró vagyok.

Szabó Kálmán évfolyamtársam volt, mint a rektor, Csizmadia is (szerk.: Csizmadia Ernő). Három rektort adott a mi évfolyamunk és öt professzort. 220-an végeztünk, megvan a névsorom, mert a találkozókat én szerveztem. Bonyolult folyamat volt az évfolyamok átlépése az új egyetemre. Azt mondták, hogy a marxizmus-leninizmus olyan tudományág, amelyet egy év alatt nem lehet elsajátítani. Az úgynevezett ideológiai jellegü tárgyakból az első két év szigorlatait meg kellett ismételni. Tehát én - mint mindenki, aki átkerült - a harmadik és negyedik év szigorlatai mellett a harmadik évfolyam idején még három szigorlatot letettem, nem önként: filozófia, gazdaságtörténet, közgazdaságtan. Ez 1948-ban volt, és 1950ben végeztem. Függetlenül attól, hogy a harmadikat hányszor jártam, a diplomaosztás előtt nem egészen egy hónappal a rektori hivatal tábláján megjelent egy hirdetés 16 névvel, akiket kizártak az egyetemről. Nincs diploma. Ök voltak a politikailag nemkívánatos elemek. Elengedték őket egészen a diplomaosztásig, s ott rúgták ki ezt a 16 embert.

\section{S. J.: Ismerte őket személyesen?}

L. Á.: Évfolyamtársam volt -a harmadikat ő is másodszor járta - egy Schöpf Lajos nevezetü fiú, az édesanyjának zöldségüzlete volt. A Szerb utcából megy egy kis utca a Kálvin térre, a Királyi Pál utca, annak a közepén volt egy zöldséges üzlete. Volt egy lehasznált, ötszemélyes Ford személyautója, aminek a hátsó 
ülését kirakták, és Lajos minden nap 5 órakor kiment Csepelre a Nagyvásártelepre, megvette az árut, bejött, felpakolta az üzletbe 7 órára, hogy az anyja kinyithasson. Letusolt és jött az egyetemre. Öt azon a címen rúgták ki, hogy „kizsákmányoló”. Elment buszsofőrnek, találkoztam vele.

- Hol dolgozol? - kérdi. Mondom: - Miért?

- Azért, mert én vezető állásban vagyok. Buszvezető állásban.

\section{S. J.: Történt később valamilyen rehabilitáció?}

L. Á.: Amikor Szabó Kálmán rektorhelyettes lett, elintézte, hogy ezek a hallgatók - bizonyos vizsgák letételével - megkaphatják a diplomát. Még ehhez a Lajos fiúhoz tartozik, hogy ő is jelentkezett, de könyvvitelből, számvitelből gyenge volt. Jött, hogy segítsek neki. Megnéztem ki vizsgáztat és mondtam neki: „Ide figyelj, ennek a fiúnak át kell menni!” Elmondtam neki, hogy mi a háttere. Azt mondta Lajos, hogy a vizsgáztató tanár kinyitotta az indexét és megkérdezte: „Schöpf Lajos, maga ismeri Laki Árpádot?” Azt válaszolta: „Az évfolyamtársam volt”. „Akkor biztosan tudja a könyvvitelt, elégséges.” Egyébként Szabó Kálmán nagyon jó képességü, tehetséges falusi gyerek volt, aki nagyon komolyan vette a munkáját a tanulásban is. Szorgalmas, tehetséges volt és a Nagy Imre féle társadalmi-politikai modellt fogadta el, azt támogatta. Erre egy konkrét példa: 1958-ban összefutok vele az Apponyi téren (szerk.: ma Ferenciek tere). -Mi van, Árpi, visszajöttél a pártba? - kérdezi.

- Nem - mondom.

- Miért nem?

- Ne hülyéskedj, ebbe a bandába?

- Te nem vagy komplett - mondta. - Pont azért kell belépni, hogy olyanok legyenek benne, mint mi. Hogy olyanra formáljuk, amilyenre mi akarjuk.

- Kálmán ne gyötörd magad, én ebbe nem szállok be - feleltem.

\section{S. J.: Ha a kezdetekre gondol, akkoriban kik voltak emlékezetes tanárai?}

L. Á.: A József Nádor Műszaki és Gazdaságtudományi Egyetemen egyértelműen Heller Farkas, aki nemzetközileg elismert közgazdász professzor volt. Elég nagy volt a nemzetközi tekintélye professzoromnak, Kuntner Róbertnek is. Kiváló tanár és ember volt a matematika professzora, Huszár Géza, aki egyébként országos hírü biztosításmatematikus volt. Egy européer, rendkívül kellemes figura, mindig úgy öltözött, mintha éppen egy párizsi szalonból jött volna ki. Bejött a Huszár Géza bácsi, és máris eltelt az óra. „Engedjék meg, hogy bemutatkozzam. Huszár Géza vagyok a matematika tanszék professzora, egyetemi nyilvános rendes tanár. Nem tudom tudják-e, mi különbség van az egyetemi nyilvános rendes és az egyetemi rendkívüli tanár között? Az, hogy az egyetemi nyilvános rendes tanár nem tud semmi rendkívülit. Az egyetemi rendkívüli tanár nem tud semmi rendeset.” Így mutatkozott be, utána felkelt, vett egy krétát, azt mondta: „Önök itt a legkülönbözőbb középiskolából jöttek, a legkülönbözőbb szinten tanulták a matematikát. Nem szeretném, ha hendikeppel indulnának azok, akiknél gyengébb volt a matematika oktatása. Ezért elölről kezdem. A matematika az arab számokat használja, amelyek így néznek ki: 1, 2, 3... Utána jön a helyiérték, a 10-es a 100-as...” Kétórás volt egy előadás, a második óra végén kétismeretlenes, vegyes másodfokú egyenlet megoldásának levezetésénél tartott. Végigvette a matekot. 


\section{A politikai párhuzamosság dinamikája - hátrányok és előnyök}

\section{S. J.: Ön miért választotta a számvitelt?}

L. Á.: Érdekelt a téma, és a harmadik évben jött a lehetőség a Számviteli Tanszéken. Így odakerültem. Aztán amikor végeztem akkor elosztottak minket, engem a villamosiparhoz. A minisztérium személyzeti főosztályán kellett jelentkezni, mert ők mondták meg, hogy a villamosipar melyik vállalatához fognak küldeni. Megmondták, hogy ki hova megy, nem választhattunk. A személyzetis leküldött a villamosenergia igazgatóságra, ez az osztály irányította az egész villamosipart. Amikor az osztályvezető érdeklődött, hogy ki vagyok, volt annyi rutinom, hogy azonnal jeleztem, az egyetem Számvitel Tanszékéröl jöttem. Ezek után annyit mondott: "Köszönöm szépen, nincs kérdésem."

\section{S. J.: Az egyetemmel való kapcsolata hogyan alakult?}

L. Á.: Amikor 1948-ban az új, önálló egyetemet megalapították, csak két vagy három tanszéken hagyták meg a professzorokat, a többit mind lecserélték. A statisztikai, matematikai és számviteli tanszéken ezekhez ugyanis nagyon nehéz marxista elméletet füzni - meghagyták. De a Számvitel Tanszéken a profot csak pozícióban hagyták, odatettek egy külsőst, akit megbíztak a tanszékvezetéssel. Aki végül azon bukott le - öt évig dolgozott ott -, hogy új tankönyvet adott ki, de valaki felismerte, hogy ez egy orosz tankönyv szó szerinti fordítása. Ezért rúgták ki.

\section{S. J.: Gyakorlatilag az összes tanárt lecserélték, akik az elözö egyetemen tanítottak?}

L. Á.: Igen, és főként moszkovitákat hoztak. Nagy Imre is moszkovita volt, Berei Andor - aki a közgazdaság tanszéken volt - szintén ehhez az irányzathoz tartozott, de a rektor és a filozófia tanszék vezetője is a moszkovita vonalhoz tartozott.

S. J.: A diákok, a hallgatók hogyan élték meg ezt a folyamatot, azt, hogy a tanáraik, a professzoraik egyik napról a másikra eltüntek?

L. Á.: Mit tehettek? Ha diplomát akartak szerezni, akkor azt mondják, amit most követelnek.

\section{S. J.: De egymás közt csak beszélgettek?}

L. Á.: Persze, de azt, hogy éppen azt a 16 diákot rúgták ki, abban az is benne volt, hogy minden osztályban voltak beépítettek emberek, besúgók.

\section{S. J.: Felvetödött, hogyan tudnak kiállni, szolidaritást vállalni azzal a 16 hallgatóval?}

L. Á.: Összefogni? Hogy? Jellemzésül a politikai légkörre, egy történet. Azt a kollégiumot, ahol addig éltünk, felszámolták, szétrúgták. Mindenkit szétszórtak NÉKOSZ jellegű kollégiumokba. Én elkerültem egy volt református kollégiumba a legjobb barátommal, akivel addig ugyanabban a kollégiumban laktunk és ő is tanszéken volt. Ezekben a kollégiumokban rendszeresen tartottak kritika-önkritika órát. Egy fiú egy rózsafüzért hozott magával, amit az édesanyjától kapott, és az egyik szobatársa emiatt beárulta A kritikaönkritika alkalom elött tanácsot kért tőlem, hogy elmondja-e. Azt tanácsoltam, hogy ne mondja el, de valahogy kiderült, és szóba hozták. Másnap mindkettőnket kitettek, és külön kollégiumban helyeztek el, nehogy közel legyünk egymáshoz. Persze a tanszéken együtt voltunk.

Az egyetemi reform előtt az egyetem hangulata, szelleme is olyan volt, mint a társadalomé. Egy polgári társadalom egyik felsőoktatási intézménye. Így müködött. Egy példa. A német nyelvtanár nagyon helyes 
ember volt, kereskedelmi levelezést tanított. A nyelvóra egy kisebb teremben volt, a terem közepén ült egy fiú és egy lány, a fiú beszélt a lányhoz. A nyelvet beszélni kell, nem hallgatni. Ezek meg ott csevegtek. Megszólalt a nyelvtanár: „Kisasszony, ne hagyja magát inzultálni a szomszédjától.” Figyeltünk, hogy ki ül ott. Eltelik tíz perc, megint megszólalt a tanár. „Kisasszony, kértem már, figyelmeztettem, ne hagyja magát zavarni!” Utána csend, megint folytatják. Fölállt a tanár katedráról, odajött és rákiáltott a fiúra: „Mars ki!”. Amikor kiment, felállt az egyik srác: „Tanár úr, nem tudom, tudja-e, hogy ez a fiú valamelyik miniszter fia.” A tanár erre azt felelte: „Nem érdekel, mert itt hallgató. Nem érdekel, kinek a fia.” Ilyen volt a régi egyetem szelleme.

Az új egyetem megalakításakor hoztak egy törvényt, hogy aki a régi egyetemről 8 érvényes félévet igazolni tud, az megkaphatja a régi szerinti diplomát, ha az összes vizsgát a régi szerint befejezi, és erre adtak egy évet. A legnehezebb a könyvvitel vizsga volt, akinek nem volt meg a könyvvitel szigorlata, az jött a tanszékre, hogy készítsük föl. Az a tanársegéd, akit a Szabó Kálmán visszahozott, azt mondta, hogy szóljunk, ha jönnek a hallgatók korrepetálásra, és elosztja köztünk. Akkoriban $1000 \mathrm{Ft}$ volt egy végzett diplomás mérnök fizetése, és egy könyvvitel szigorlatra való felkészítés 16 órában $800 \mathrm{Ft}$ volt. Én akkor az ebből megkeresett jövedelemből csináltattam egy gyönyörü szilvakék öltönyt. Az egyik tanítványtól, akinek suszter kisiparos volt az apja, kaptam egy gojzer varrott cipőt. Amikor megkapta a diplomát, megkeresett: „Árpi, húzd le a cipőd.” Lehúztam, erre méretet vett és egy hét múlva hozta az új cipőt ajándékba. Pár nap múlva jött Huszár Pista, - aki később a Tervhivatal elnöke lett. „Ne öltözz így Árpi, mert a kollégium pártvezetőségében megszóltak, hogy ez milyen polgári attitüd, és mit keres egy ilyen a kollégiumban." - mondta. De akkor engem ez már nem zavart, ha kirúgnak sem.

\section{S. J.: Hogy alakult a végzés utáni szakmai pályája, amikor nem volt szabad a munkaeröpiac?}

L. Á.: Egy külsős kolléga hívott a villamosiparba, mert az egy jó hely. Szóltam azoknak, akik az elosztási javaslatot csinálták, hogy a villamosiparba szeretnék menni. Miután a tanszéken voltam, ezt megtették nekem, úgyhogy oda helyeztek. Első két évben egy villamoströsztben dolgoztam, utána négy évet a minisztériumban az irányító igazgatóságon 1957-ig. 1956-ban nem viselkedtem támogatólag a Kádár-féle koncepcióhoz, s ezért eltanácsoltak a minisztériumból. Nem bántottak, csak kitettek egy vállalathoz. Ott nem egészen egy évet dolgoztam, amikor a tröszt vezérigazgatója felhívott: „Gyere hozzánk, vezesd a gazdasági ellenőrzési osztályt!” Ezt a munkát végeztem 1957-től 1963-ig, tehát hat évig. Törvény írta elő, hogy minden vállalatnál belső ellenőrzést kell létrehozni. A trösztnél a belső ellenőrzés feladata volt a vállalatainak ellenőrzése. A villamosenergia trösztnek 22 vállalata volt. A szolgáltató, Budapest, Győr, Pécs, Debrecen és Miskolc, az erőművek, volt vagy 8 , köztük az atomerőmű és hasonlók. Tehát az egész villamosipar belső ellenőrzése ennek az osztálynak volt a feladata. A trösztben összesen öt közgazdász volt, abból velem együtt három az én osztályomon. Már két-három hét után rágtam a vezér fülét, hogy ez a csavargó élet nem jó nekem, a kollégáim kint a területen dolgoztak, nekem kellett indítani, zárni. Aztán 1963-ban - akkor 38 éves voltam - az iparág egyik legnagyobb budapesti vállalatához kerültem gazdasági igazgatónak, később vezérigazgató-helyettesként végeztem ugyanazt a munkát. Ott dolgoztam 65 éves koromig, akkor nyugdíjba mentem. Még a hat hónapos sétálóidőben voltam (felmentettek a munka alól), amikor jelentkeztem egy multinacionális világcéghez, ahol 75 ezer ember dolgozik, és a világon mindenütt vannak vállalatai. Itt egy év után partner lettem, és még tíz évet (75 éves koromig) ledolgoztam. Három év után -könyvvizsgálói diplomával is rendelkezem - a cég könyvvizsgálói bevételének 65 százalékát én szerveztem be a céghez. Villamosipar, MÁV, Állami Fejlesztési Bank, Bábolna, csak hogy a nagyokat mondjam. Voltam az OTP-nek is könyvvizsgálója. Negyven éve dolgozom a Számvitel Tanszéken. Felbecsülhetetlen, amit a tanszéki munka nyújtott. Tessék elképzelni - gazdasági területen dolgozom, a 
villamosiparban végig vezető állásban -, hogy nem volt olyan országos gazdasági irányító-vezető szervezet, ahol a vezetőgarnitúrának legalább a fele ne lett volna közvetlen ismerősöm, haverom, valamilyen kapcsolatom, legyen szó akár a Pénzügyminisztériumról, Tervhivatalról vagy a párt gazdaságpolitikai osztályáról.

S. J.: Nyilván ennek volt köszönhetö, hogy a rendszerváltás után is fontos szakmai pozíciókban lehetett.

L. Á.: A rendszerváltáskor megérkezett Magyarországra a Big Four, a négy nagy könyvvizsgáló cég, a Deloitte, az Ernst \& Young, a PwC és a KPMG. Számítottak a szakmai tapasztalataimra, meg a networkömre, helyismeretemre, ami nagyon fontos volt számukra, hiszen majdnem ismeretlen terepre érkeztek. Jelenleg is tanácsadója vagyok a KPMG-nek. Személyes - nem azt mondom, hogy baráti, de közvetlen - kapcsolatom volt és van két miniszterelnökkel, Medgyesivel és Németh Miklóssal. Németh Miklós miniszterelnöksége idején a Tervhivatal elnöke nálam volt ösztöndíjas, most is összejárunk. Olyan háttérrel rendelkeztem, ami egy nagyvállalat, egy multi számára is értéket jelentett. Azon kívül sokféle emberrel tudtam együtt dolgozni. 15 évig egy olyan vezérigazgatóval dolgoztam, akit, ha cégem volna, nem vennék fel még portásnak sem, nem a képességei, hanem a jelleme meg a habitusa miatt. De tudtam kezelni. Nem felejtem el, egyszer Kovács Árpád, aki az ÁSZ elnöke volt, vállalatvezetőknek adott elő egy konferencián, ahová ezzel a vezérigazgatóval együtt mentem el. Egymás mellett ültünk, aztán jött Árpád a sorok között, meglátott, üdvözölt. A vezérigazgató suttogva kérdezte: „Te ezt ismered? Nekem is van ám ismerősöm odaát a számvevőségen.” Ez a vezérigazgató mindig ezzel menedzselte magát, amikor ment be a minisztériumba vagy a pártbizottságba: „Képzeljétek el, nekem milyen nehéz dolgom van. Két helyettesem van, mindkettő párton kívüli."

Az egyetemen 70 éves koromig tanítottam, és kapcsolataimat később is az egyetem, az oktatás, a hallgatók javára fordítottam.

Sipos Júlia ${ }^{2}$

2 tudományos újságíró 